\title{
MAGNETIC NANOCOMPOSITES FOR BIOMEDICAL APPLICATIONS
}

\author{
NANOKOMPOZYTY MAGNETYCZNE DO ZASTOSOWAŃ \\ BIOMEDYCZNYCH
}

\author{
Marta IZYDORZAK-WOŹNIAK ${ }^{1}$, Marcin LEONOWICZ ${ }^{1}$
}

\begin{abstract}
Magnetic carbon nanocomposites (MCNCs), with different constitution and fractions of magnetic component, were fabricated by the pyrolysis of the polymeric precursor. $\mathrm{X}$-ray diffraction, transmission electron microscopy and Raman spectroscopy revealed the presence of nanocrystallites ( $\mathrm{NCs}$ ) of $\mathrm{Co}, \mathrm{Fe}_{3} \mathrm{C}$ and $\mathrm{Ni}$ embedded in porous, partially graphitized carbon matrix. Vibrating sample magnetometer measurements enabled to determine the correlation between NCs size distribution and magnetic properties. The magnetic studies confirmed that the coercivity, saturation and remanent magnetizations, as well as fraction of the magnetic component depend on the pyrolysis temperature. The $\mathrm{Co} \# \mathrm{C}$ and $\mathrm{Fe}_{3} \mathrm{C \# C}$ composites exhibited ferromagnetic behaviour with a remanent to saturation magnetization $\left(\mathrm{M}_{\mathrm{R}} / \mathrm{M}_{\mathrm{S}}\right)$ ratio ranging from 0.25 to 0.3 , whereas in the $\mathrm{Ni}$ containing samples a relatively small $\mathrm{M}_{\mathrm{R}} / \mathrm{M}_{\mathrm{S}}$ ratio points to significant contribution of superparamagnetic interactions.
\end{abstract}

The Ni\#C composites, having superparamagnetic and/or ferromagnetic nanocrystallites in their volume, were chosen to check the ability of heat generation in a magnetic field. It was found that the hysteresis losses were the main mechanism of heat generation. The MCNCs obtained can potentially be applied for hyperthermia treatment.

As the MCNCs are proposed for biomedical application the basic cytotoxicity test were performed to evaluate a potential toxic effect of the materials on MG-63 cells line. The test results confirmed that the composites containing $\mathrm{Fe}_{3} \mathrm{C}$ are non-cytotoxic whereas the majority of the Ni\#C and Co\#C composites was characterized as slightly or moderately cytotoxic.

Keywords: magnetic carbon nanocomposite, magnetic properties, pyrolysis, cytotoxicity, biomedicine

Streszczenie: Magnetyczne nanokompozyty o osnowie węglowej (MCNCs), zawierające różną zawartość i budowę fazową metalicznego komponentu, zostały wytworzone poprzez pirolizę polimerowego prekursora. Dyfrakcja rentgenowska, transmisyjna mikroskopia

\footnotetext{
${ }^{1}$ Warsaw University of Technology, Faculty of Materials Science and Engineering, ul. Wołoska 141, 02-507

Warsaw, Poland
} 
elektronowa i spektroskopia Ramana wykazały obecność nanokrystalitów (NCs) $\mathrm{Co}, \mathrm{Fe}_{3} \mathrm{C}$ i Ni umiejscowionych w porowatej, częściowo zgrafityzowanej węglowej osnowie. Badania właściwości magnetycznych potwierdziły, że koercja, namagnesowanie nasycenia i remanencja oraz zawartość magnetycznego komponentu zależą od temperatury pirolizy. Kompozyty Co\#C i $\mathrm{Fe}_{3} \mathrm{C \# C}$ wykazują właściwości ferromagnetyczne, ze stosunkiem remanencji do namagnesowania nasycenia $\left(\mathrm{M}_{\mathrm{R}} / \mathrm{M}_{\mathrm{S}}\right) \mathrm{w}$ zakresie $0,25-0,3$, podczas gdy dla kompozytów zawierających Ni stosunek $\mathrm{M}_{\mathrm{R}} / \mathrm{M}_{\mathrm{S}}$ wskazuje na znaczący wkład od oddziaływań superparamagnetycznych. Kompozyty $\mathrm{Ni} \# \mathrm{C}$, zawierające nanokrystality ferromagnetyczne lub superparamagnetyczne zostały wybrane do zbadania zdolności do generowania ciepła w zmiennym polu magnetycznym. Stwierdzono, że straty na histerezę odgrywają decydującą role w generowaniu ciepła. Wytworzone MCNCs mogą zatem być potencjalnie stosowane w hipertermii.

Badania cytotoksyczności, przeprowadzone $\mathrm{z}$ zastosowaniem linii komórkowej MG-63 wykazały, że kompozyty zawierające $\mathrm{Fe}_{3} \mathrm{C}$ są nietoksyczne, natomiast większość kompozytów Ni\#B and Co\#C można określić jako mało lub umiarkowanie toksyczne.

Słowa kluczowe: nanokompozyt magnetyczny, właściwości magnetyczne, piroliza, cytotoksyczność, biomedycyna

\section{INTRODUCTION}

Magnetic carbon nanocomposites (MCNCs) become increasingly more popular in many applications, including biomedicine, where carbon matrix protects nanocrystallites from corrosion and potential toxic side effects. It might turn out particularly useful for biomedical in vivo applications in diagnostic applications such as MRI [1] and therapies such as sitespecific drug delivery [2,3] and magnetic particle hyperthermia [4,5]. MCNCs, in a form of microparticles (or microspheres), with embedded magnetic cores are especially proposed for in vitro applications [6,7] e.g. magnetic bioseparation. Due to the interaction of microparticles with an external magnetic field, the separation procedure is much faster, easier and cheaper, since the time consuming stages of filtration and centrifuging can be avoided. Nevertheless, it was also reported that carbon microparticles of size in the range $0.5 \div 5 \mu \mathrm{m}$ may potentially be used for in vivo applications e.g. chemotherapy [2,8]. In this case other routes of administration to targeted place are required including intra-arterial administration [2] or catheterization $[3,8,9]$. The latter method is based on the placement of magnetic microparticles in the blood vessel, which feeds the tumour and subsequently their transportation by a magnetic field forces into the cancer cells. There are no obstacles to use the same material, not only to transport the drug to the desirable place, but also for moderate hyperthermia. In such a case, cancer cells are weakened by applying a higher temperature in the range of $41-46^{\circ} \mathrm{C}$ [10]. In a consequence, the cells undergoing heat stress are much more prone to a medication therapy. The combination of both, hyperthermia-based therapy and controlled drug delivery, supply an extremely powerful and efficient tool in the fight against tumours and other diseases.

In this work, carbon matrix magnetic nanocomposites, in a form of mesoporous powder particles with embedded cobalt, iron carbide and nickel nanocrystallites were synthesized by pyrolysis of polymers containing metal atoms and characterized. 


\section{EXPERIMENTAL}

For synthesis of the carbon composites, built-up of $\mathrm{Fe}_{3} \mathrm{C}$, $\mathrm{Co}$ and $\mathrm{Ni}$ nanocrystallites embedded in a carbon matrix (later called $\mathrm{Fe}_{3} \mathrm{C \# C}$, Co\#C and $\mathrm{Ni \# C}$ nanocomposites, respectively), a 3-stage process was implemented. The first stage was an acrylamide complex (monomer) synthesis. The reactant mixtures contained hydrates of inorganic salts (Me nitride, $\mathrm{Me}=\mathrm{Fe}, \mathrm{Co}, \mathrm{Ni})$ and acrylamide (AAm). Then a monomer was polymerized. At the end of the process pyrolysis of the polymer was carried out at a temperature of 773,873 and $1073^{\circ} \mathrm{K}$, respectively. A more detailed description of the processing route can be found in [11].

A set of experimental methods was used for characterization of the properties of the Co, $\mathrm{Fe}_{3} \mathrm{C}$, and $\mathrm{Ni}$ nanocomposites. The morphology and phase constitution was studied using a Rigaku MiniFlexII X-ray diffractometer equipped with a copper cathode ( $\lambda$ (Cu$\left.\mathrm{K}_{\alpha}\right)=0.154184 \mathrm{~nm}$ ), in a scan range $(2 \theta)$ from $20^{\circ}$ to $100^{\circ}$, a scanning electron microscope (SEM, Hitachi S-3500N) and analysed using a scanning transmission electron microscope (STEM, JEOL JEM 1200 EX). To prepare TEM samples, small quantity of powder was dispersed in ethanol, subjected to 5-minute ultrasonification and afterwards a few drops of the resulting suspension was deposited on a holey carbon TEM grid and dried at ambient conditions. Raman spectra were obtained using Raman spectrometer (Nicolet Almega XR) with $532 \mathrm{~nm}$ laser excitation wavelength. Nanocomposite size distribution was determined by applying a Laser Scattering Particle Size Distribution Analyzer (Horiba LA-950), for powders before and after ball milling for 30 minutes and a frequency of $f=15 \mathrm{~Hz}$ (Retsch CryoMill). Measurements were carried out after 10-minute ultrasonification in order to shatter agglomerates. The magnetic properties were evaluated using vibrating sample magnetometer (VSM Lake Shore 7410), on the basis of hysteresis loops recorded at room temperature, in an external magnetic field of $\pm 800 \mathrm{kA} \cdot \mathrm{m}^{-1}$.

The cytotoxicity effect was checked for various extraction concentrations $(50,25,12.5,6.25$, $3.125 \mathrm{mg} / \mathrm{ml}$ ). For the assessment of cells reaction, microscopic observations and a cell proliferation kit XTT was used. The latter is based on a measurement of a metabolic activity of cells in the in vitro culturing. MG-63 cell line, a human osteosarcoma cell line was used in the in vitro tests. The extraction vehicle consisted of Dulbecco's Modified Eagles Medium (DMEM) supplemented with fatal bovine serum, L-glutamine and antibiotic.

\section{RESULTS}

The nanocomposites, after the final procedure step, regardless their chemical composition, were in a form of black irregular powder microparticles, having sizes ranging from few up to hundreds microns (Fig. 1). The SEM observations revealed that the variation of the pyrolysis temperature seemed not to cause any dramatic changes neither to the shape nor to the size of the powder particles.

Selected samples were subjected to milling in order to narrow down the particle size distribution (Fig. 2a and b). For the as-prepared sample the particle size distribution indicated a bimodal character. Among the particles of several microns large objects, sometimes exceeding $300 \mu \mathrm{m}$, were distributed. The particle size distribution pattern in Figure 1b clearly shows that the subjected ball milling resulted in a constricted, unimodal distribution. Only $10 \%$ of the particles had diameter greater than 6.4 microns. 


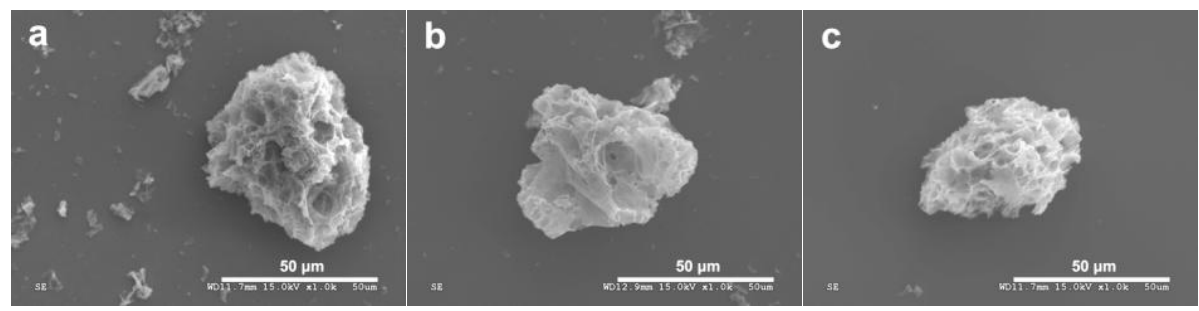

Figure 1. SEM images of (a) Co\#C 773, (b) Co\#C 873 and (c) Co\#C 1073
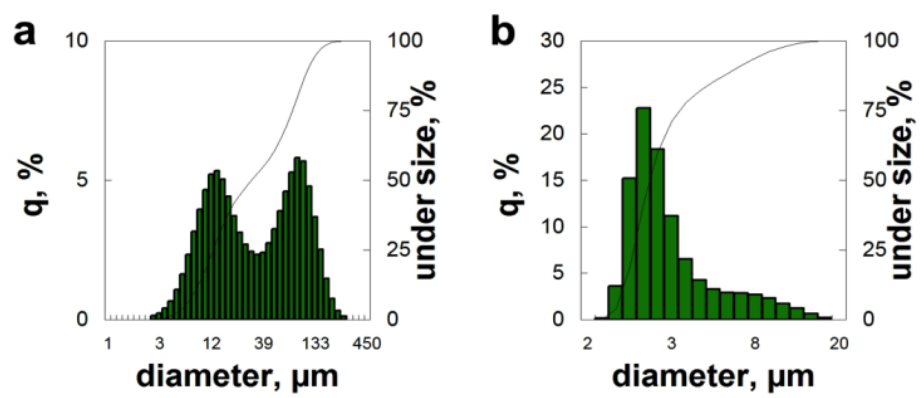

Figure 2. Particles size distribution of Co\#C 773 sample (a) before milling, (b) after milling in a Cryomill Retsch

The XRD patterns clearly indicate the presence of cobalt, nickel and the orthorhombic crystal structure of iron carbide for $\mathrm{Co}, \mathrm{Ni}$ and Fe precursors, respectively. The driving up of the baseline in the range $20^{\circ}-30^{\circ}$ in Figures $3 \mathrm{a}$ and $3 \mathrm{c}$ is probably contributed by amorphous carbon. However, for the samples Co\#C 1073 and Ni\#C 873 a clear diffraction peak at about $26^{\circ}$, assigned to the graphite plane $d_{002}$ is seen. As the pyrolysis temperature increases, the degree of graphitization seems to increase, for all the samples. For the nanocomposites obtained from iron precursor the graphite-like carbon is present in the sample obtained at $873 \mathrm{~K}$.
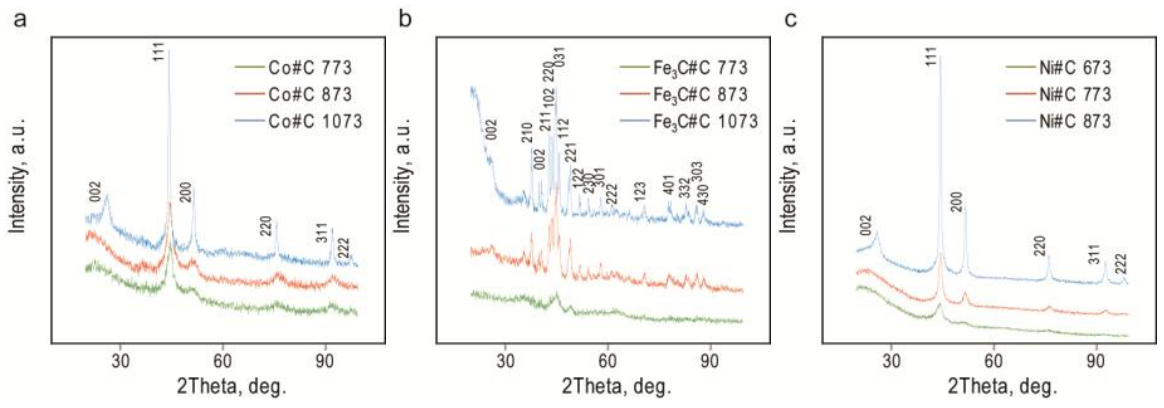

Figure 3. X-ray diffraction patterns of (a) $\mathrm{Co \# C}$, (b) $\mathrm{Fe}_{3} \mathrm{C \# C}$ and (c) Ni\#C nanocomposites

Further information concerning the structure of the carbon matrix was obtained from Raman spectroscopy (Fig. 4). Representative Raman spectra of the $\mathrm{Fe}_{3} \mathrm{C \# C}, \mathrm{Co \# C}$ and $\mathrm{Ni \# C}$ 
nanocomposites pyrolysed at $873 \mathrm{~K}$ show two characteristic bands, the main graphite band, so-called $\mathrm{G}$ band, centred at $\sim 1580 \mathrm{~cm}^{-1}$ and the $\mathrm{D}$ band located at $\sim 1350 \mathrm{~cm}^{1}[12,13]$. The G band of hexagonal graphite is attributed to the stretch vibration of $\mathrm{sp}^{2}$-hybridized carbon atoms in the graphite layer, whereas the D band is the consequence of carbon atoms vibration of defected graphite lattice or amorphous carbon [14]. It is associated with the defects presented in the carbon aromatic structure. Moreover, the width of the bands and intensity ratio of G/D band gives information on the graphitization degree of the carbon matrix [15]. For each sample the G/D ratio is more or less about 1 , which reflects a relatively low graphitization degree and the presence of disordered carbon in the obtained composites. It is coherent with the results of X-ray diffraction analysis.

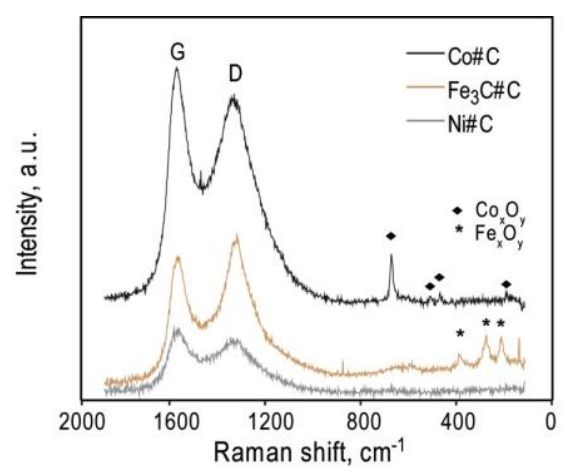

Figure 4. Raman spectra of carbon nanocomposites pyrolysed at $873 \mathrm{~K}$

Raman spectra, performed for the $\mathrm{Co}$ and $\mathrm{Fe}_{3} \mathrm{C}$ carbon nanocomposites, also indicate the presence of oxides, which apparently form on the surface of some nanocrystallites, unprotected by the carbon matrix. This phenomenon was not observed for the sample containing nickel. The Raman spectra of the Co\#C composite show the bands at 468, 512, 607, $676 \mathrm{~cm}^{-1}$ (assigned to $\mathrm{Co}_{3} \mathrm{O}_{4}$ ), however, a presence of other Co oxides cannot be excluded (for instance $\mathrm{CoO}$ with bands at $607,676 \mathrm{~cm}^{-1}$ ). The Raman spectra of the sample containing $\mathrm{Fe}_{3} \mathrm{C}$ depicts strong bands at 281 and $217 \mathrm{~cm}^{-1}$ and two other ones, with low intensities, at about 400 and $600 \mathrm{~cm}^{-1}$ (assigned to $\alpha-\mathrm{Fe}_{2} \mathrm{O}_{3}$ (hematite)). Other oxidation products of the $\mathrm{Fe}_{3} \mathrm{C \# C}$ sample can also exist, for instance $\mathrm{Fe}_{3} \mathrm{O}_{4}$ (magnetite) or $\alpha-\mathrm{FeOOH}$ (goethite). However, due to the lower stability of these phases, under the action of a laser beam, a heat-induced phase transition and oxidation of these phases to $\mathrm{Fe}_{2} \mathrm{O}_{3}$ can occur. The presence of oxidation products is not seen in the XRD patterns, which can evidence their thin layer on the nanocrystallites surface.

The nanocrystallites size distribution in the composites is shown in Figure 5 and the respective mean values are collected in Table 1.

Analyses for the Co\#C composites show that the core sizes are in the range of 7-18, 7-19 and $6-50 \mathrm{~nm}$ for the samples pyrolysed at 773, 873 and $1073 \mathrm{~K}$, respectively. For the each Co\#C composite the obtained histograms can be satisfactorily described by a lognormal function centred at $\tau(\sigma)=13(2), \tau(\sigma)=15(2.07), \tau(\sigma)=12(2.35)$ for Co\#C773, Co\#C 873 and Co\#C 1073, respectively. It is worth noting that the results obtained from TEM images analysis support the XRD data where the narrower and more intensive peaks were observed with increasing the pyrolysis temperature. 
Applying a higher pyrolysis temperature resulted in a broader size distribution of Co nanocrystallites. The main size for the sample Co\#C 773 is $12 \mathrm{~nm}$ with a standard deviation of $1.83 \mathrm{~nm}(0.15 \mathrm{CV})$, while the sample pyrolysed at $1073 \mathrm{~K}$ gains the same measured size but with greater standard deviation of $5.61 \mathrm{~nm}(0.48 \mathrm{CV})$. This was because of the broader nanocrystallites size distributions.

Table 1. Mean crystallite size for the $\mathrm{Co \# C}, \mathrm{Fe}_{3} \mathrm{C \# C}$ and Ni\#C nanocomposites pyrolised at temperatures 773,873 and $1073 \mathrm{~K}$, respectively

\begin{tabular}{|l|c|c|c|c|c|c|c|c|c|}
\hline Sample & $\begin{array}{c}\text { Co\#C } \\
773\end{array}$ & $\begin{array}{c}\text { Co\#C } \\
873\end{array}$ & $\begin{array}{c}\mathrm{Co} \# \mathrm{C} \\
1073\end{array}$ & $\begin{array}{c}\mathrm{Fe}_{3} \mathrm{C \# C} \\
773\end{array}$ & $\begin{array}{c}\mathrm{Fe}_{3} \mathrm{C \# C} \\
873\end{array}$ & $\begin{array}{c}\mathrm{Fe}_{3} \mathrm{C \# C} \\
1073\end{array}$ & $\begin{array}{c}\mathrm{Ni \# C} \\
673\end{array}$ & $\begin{array}{c}\mathrm{Ni \# C} \\
773\end{array}$ & $\begin{array}{c}\mathrm{Ni \# C} \\
873\end{array}$ \\
\hline $\begin{array}{l}\text { Cryst. } \\
\text { size } \\
{[\mathrm{nm}]}\end{array}$ & 12 & 13 & 12 & 9 & 22 & 33 & 8 & 16 & 15 \\
\hline
\end{tabular}

The nanocrystallites size increase might have occurred by coalescence of neighbouring nanocrystallites or by diffusion of metal atoms from smaller particles to the larger ones, resulting in particles, whose symmetry diverged from the singular entities $[16,17]$. The latter phenomenon is similar to Ostwald ripening of precipitates [18]. In brief, the thermally activated Ostwald ripening is driven by internal pressure, which is reversely proportional to the diameter of the particles.
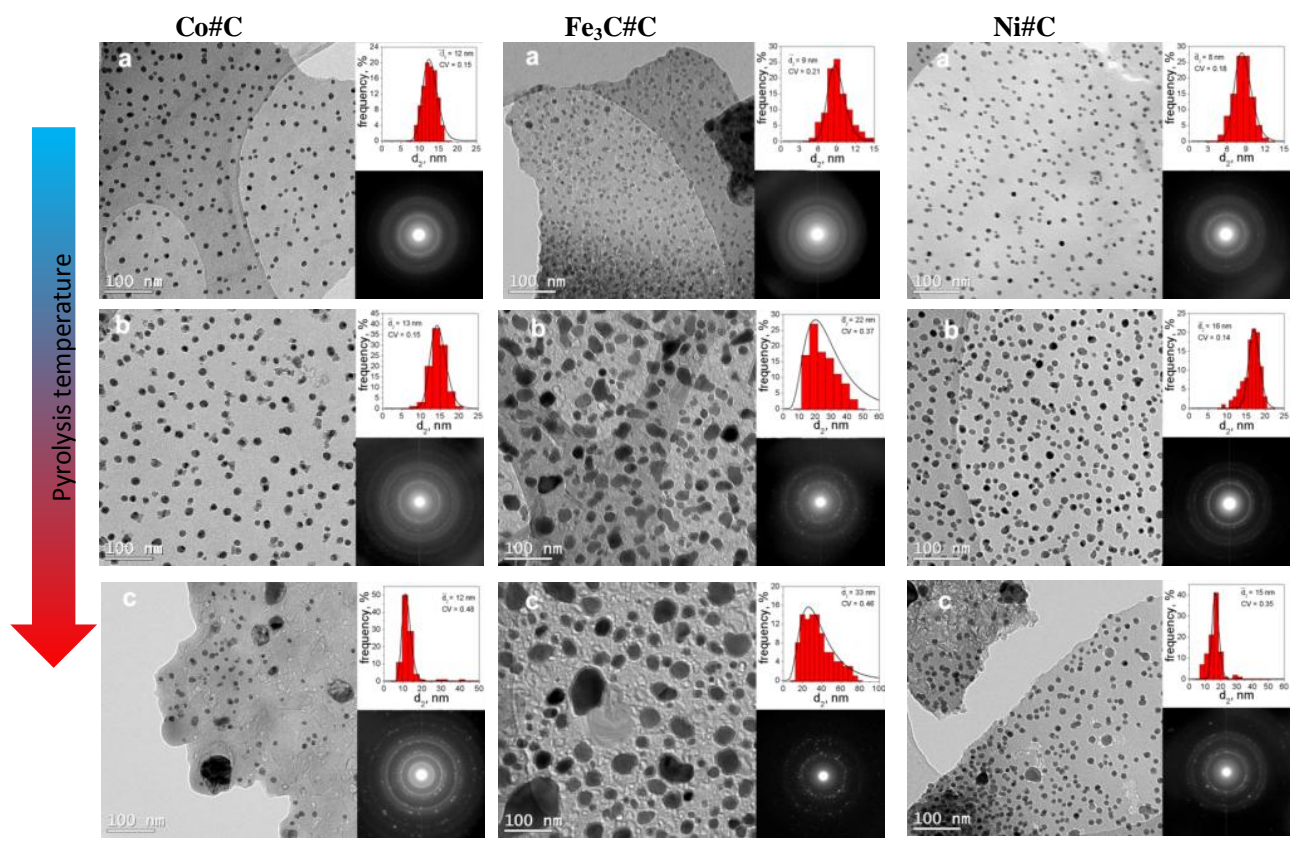

Figure 5. TEM images for the Co\#C, $\mathrm{Fe}_{3} \mathrm{C \# C}$ and Ni\#C nanocomposites pyrolysed at (a) 773, (b) 873 and (c) $1073 \mathrm{~K}$; top inset - nanocrystallites size distribution pattern, bottom inset - SAED pattern 
As the nanoscale system tries to lower its overall energy, small (energetically unfavourable) particles will tend to detach and diffuse through material and finally attach to the surface of larger particle. In other words, larger particles will grow at the expenses of smaller particles $[17,19]$.

The inter-layer distances in the sample $\mathrm{Fe}_{3} \mathrm{C \# C} 773$ correspond to the parameters: 0.251 , $0.207,0.161,0.145$ and $0.120 \mathrm{~nm}$, which coincides exactly with the d spacing in iron oxide $\left(\mathrm{Fe}_{3} \mathrm{O}_{4}\right.$ and/or $\left.\mathrm{Fe}_{2} \mathrm{O}_{3}\right)$. The different phases of iron were identified for the $\mathrm{Fe}_{3} \mathrm{C \# C} 873$ and $\mathrm{Fe}_{3} \mathrm{C} \# \mathrm{C} 1073$ samples, where not only iron oxide but also bcc $\mathrm{Fe}$ was present. The SAED patterns for these composites display also diffused rings (002), (100) and (110) deriving from carbon matrix. The presence of both iron carbide (XRD) and pure iron (SAED) may indicate the incomplete decomposition of iron carbide, which is usually accompanied by the formation not only of a graphite phase but also a pure iron [20]. However, it requires further studies for a better understanding of these phenomena.

Analyses for the Ni\#C composites reveal that the nanocrystallites size are in a range of 4-12 $\mathrm{nm}$ for Ni\#C 673, 8-20 nm for Ni\#C 773 and 5-49 $\mathrm{nm}$ for Ni\#C 873. The inter-layer distance of the metallic cores were calculated to be $0.207,0.177,0.126$ and $0.106 \mathrm{~nm}$, which is consistent with that of fcc Ni planes: (111), (200), (220) and (311), respectively. Only for the sample obtained at $873 \mathrm{~K}$ the diffraction ring with the d-spacing of $0.34 \mathrm{~nm}$ was observed, which is close to that of the graphite planes (002). It is worth noting that there is no evidence for nickel carbide or nickel oxides formation. Therefore, it seems that Ni has a better ability to associate with carbon in comparison to $\mathrm{Co}$ and $\mathrm{Fe}$, thus resulting in more effective protection against metal oxidation. The similar phenomenon was noted by Fernandez-García and co-workers [21] in the investigation on carbon-encapsulated nickel NCs prepared by a sucrose-based synthetic strategy.

As in the case of composites containing $\mathrm{Co}$ and $\mathrm{Fe}_{3} \mathrm{C}$, for the $\mathrm{Ni \# C}$ nanocomposites for temperature pyrolysis of $873 \mathrm{~K}$, there was also an increase of large particles at the expense of the small ones. Increasing the pyrolysis temperature led to broader size distribution, which can be evidenced by the increase of the values of mean nanocrystallites size from $8 \mathrm{~nm}$ with a standard deviation of $1.83 \mathrm{~nm}(0.18 \mathrm{CV})$ for $673 \mathrm{~K}, 16 \mathrm{~nm}$ with std dev of $2.17 \mathrm{~nm}(0.14 \mathrm{CV})$ for $773 \mathrm{~K}$, up to $15 \mathrm{~nm}$ with std dev of $5.13 \mathrm{~nm}(0.35 \mathrm{CV})$. These values are somewhat consistent with the mean Ni nanocrystallites size estimated by Scherrer equation to be 6, 9 and $17 \mathrm{~nm}$ for N\#C 673, Ni\#C 773 and Ni\#C 873, respectively.

The hysteresis loops for the Co\#C composites (Fig. 6a) indicate that all the samples exhibit ferromagnetic behaviour at room temperature. Notwithstanding the foregoing, a ratio of remanent to saturation magnetization $\left(\mathrm{M}_{\mathrm{R}} / \mathrm{M}_{\mathrm{S}}\right)$ below 0.25 might point at the presence of some proportion of the nanocrystallites in a superparamagnetic state [22]. The corresponding room temperature $\left(\mathrm{T}_{\mathrm{R}}\right)$ saturation magnetization is $19.8,39.7$ and $55.4 \mathrm{~A} \cdot \mathrm{m}^{2} / \mathrm{kg}$, respectively, which is much lower than the $\mathrm{M}_{\mathrm{S}}$ of the bulk cobalt $\left(161 \mathrm{~A} \cdot \mathrm{m}^{2} \mathrm{~kg}\right.$ ${ }^{1}$ at $\mathrm{T}_{\mathrm{R}}$ ) and is caused by the contribution from carbon matrix but it can also by affected by the presence of other phases including cobalt oxides. Assuming that the magnetic properties only stem from the metallic cobalt and the contribution of cobalt dioxide is negligible, the content of the magnetic component $\left(\mathrm{F}_{\mathrm{mc}}\right)$ values were extrapolated to be 12,25 and $34 \mathrm{wt} . \%$ for the samples pyrolysed at 773,873 and $1073 \mathrm{~K}$, respectively.

For the samples prepared from iron precursors, the data imply a ferromagnetic behaviour as indicated by the open hysteresis loops, i.e. non-zero remanence and coercivity, and the relatively high values of remanence/saturation $\left(M_{R} / M_{S}\right)$ ratio (Fig. 6b). The enhanced $M_{R} / M_{S}$ 
ratio for the both Fe\#C873 K and Fe\#C1073 indicates the existence of exchange magnetic interaction in these samples [23,24]. Moreover, due to the relatively large mean nanocrystallites size of $\mathrm{Fe}_{3} \mathrm{C}$, calculated by TEM images, a superparamagnetic contribution can hardly be observed for these composites. On the contrary to the sample pyrolysed at $773 \mathrm{~K}$, the $\mathrm{M}_{\mathrm{R}} / \mathrm{M}_{\mathrm{S}}$ was 0.11 , which points that the nanocrystallites assembly can contain smaller entities in a superparamagnetic state. Comparing obtained data with the value of $\mathrm{M}_{\mathrm{s}}$ of the bulk iron carbide $\left(140 \mathrm{~A} \cdot \mathrm{m}^{2} \mathrm{~kg}^{-1}\right.$ at $\left.\mathrm{T}_{\mathrm{R}}\right)$, the $\mathrm{F}_{\mathrm{mc}}$ are 8,24 and $28 \mathrm{wt}$. \%, respectively. The VSM yields coercivity $8,46.4$ and $40 \mathrm{kA} / \mathrm{m}$ for $\mathrm{Fe}_{3} \mathrm{C} \# \mathrm{C} 773, \mathrm{Fe}_{3} \mathrm{C \# C} 873$ and $\mathrm{Fe}_{3} \mathrm{C} \# \mathrm{C}$ 1073, respectively, at room temperature. In such a nanosystem, consisting of randomly distributed magnetic nanocrystallites entrapped in a diamagnetic matrix, strong magnetic interactions are expected. Besides, it is found that the relatively large coercivity can be attributed the size close that size of single domain particles, where the maximum of $\mathrm{H}_{\mathrm{c}}$ occurs. It is reported the coercivity mechanism in nanosystems is a complex mixture of several mechanisms including coherent rotations, pinning and superparamagnetism.

Magnetic $\mathrm{M}(\mathrm{H})$ curves for the Ni\#C composites (Fig. 6c) exhibit near-zero coercive force and remanence values, suggesting a high superparamagnetic contribution in the materials. It coincides with the relatively low $\mathrm{M}_{\mathrm{R}} / \mathrm{M}_{\mathrm{S}}$ ratio for the samples prepared at 673 and $773 \mathrm{~K}$. In the case of the sample Ni\#C 873, a mixture of both superparamagnetic and ferromagnetic particles due to broad nanocrystallites size distribution might be expected. The corresponding saturation magnetization amounted to $3.9,11.4,13.2 \mathrm{~A} \cdot \mathrm{m}^{2} \mathrm{~kg}^{-1}$ increasing with the increase in percentage fraction of metallic nickel, being 8, 22 and $26 \mathrm{wt} \%$ respectively. The low $\mathrm{M}_{\mathrm{S}}$ value for these samples in comparison to the Ms of bulk nickel $\left(51.3 \mathrm{~A} \cdot \mathrm{m}^{2} \mathrm{~kg}^{-1}\right.$ at $\left.\mathrm{T}_{\mathrm{R}}\right)$ can be explained partly by the small volume fraction of the metallic component. But yet, if the assembly of fine particles is concerned, the surface effect, spin canting and sample inhomogeneity, which can make a contribution to reducing the $\mathrm{M}_{\mathrm{S}}$, cannot be neglected.
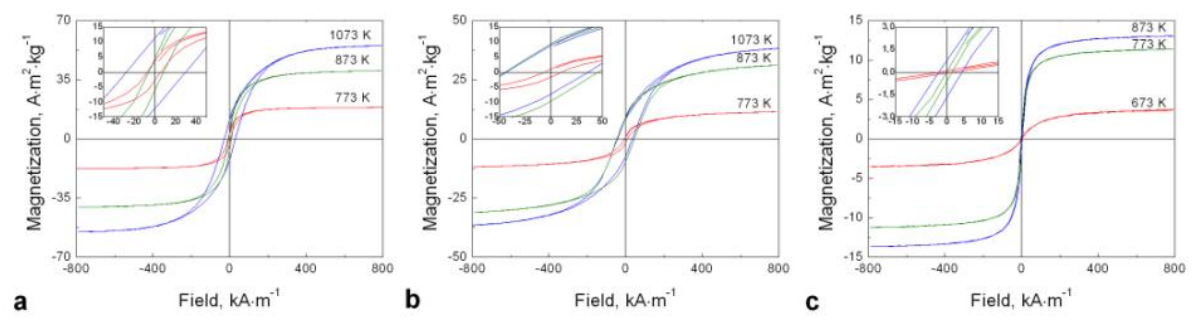

Figure 6. Hysteresis loops of (a) Co\#C composites, (b) $\mathrm{Fe}_{3} \mathrm{C \# C}$ composites and (c) Ni\#C composites obtained at room temperature

In a view of the above findings, the VMS results for Ni\#C composites, the zero-field-cooled (ZFC) and field-cooled (FC) curves as a function of temperature were recorded (Fig. 7).

The FC magnetization curve looked similar for all samples and decreased with temperature, presenting reduction of the magnetic moment. The ZFC curves for Ni\#C 673 and Ni\#C 773 had a maximum centred at about 39 and $141 \mathrm{~K}$, respectively, indicating the blocking temperature $\left(\mathrm{T}_{\mathrm{B}}\right)$. The presence of a broad hump on the ZFC for the sample Ni\#C 773 was a consequence of the wide nanocrystallites size distribution. Therefore, it is better to assume that there would rather be a distribution of $T_{B}$ than only one single $T_{B}$. Different behaviour 
was observed for the material pyrolysed at $873 \mathrm{~K}$, where ZFC magnetization did not show a maximum within the applied temperature range. This behaviour indicates that the magnetic properties are controlled by magnetostatic interactions and the composite presents ferromagnetic ordering.
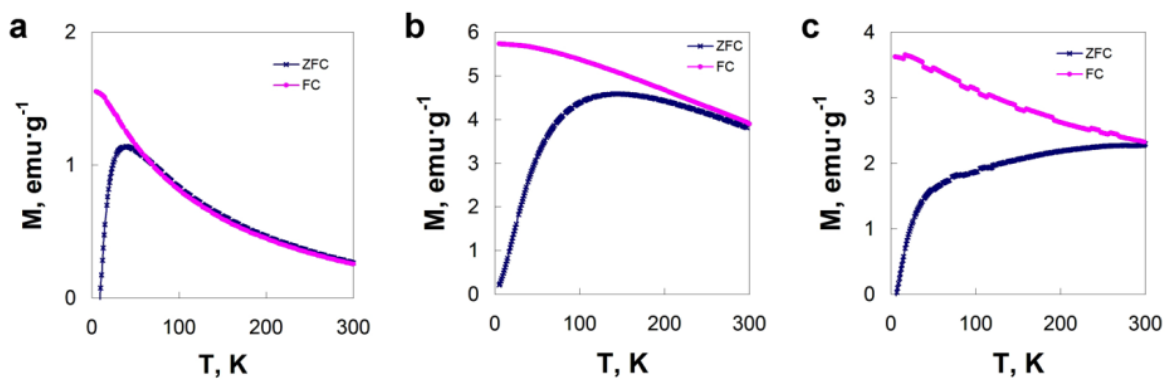

Figure 7. The zero-field-cooled (ZFC) and field-cooled (FC) magnetizations curves for Ni\#C samples pyrolysed at (a) 673, (b) 773 and (c) $873 \mathrm{~K}$

Figure 8 presents the time changes of the Ni\#C samples temperature, for specimens subjected to an alternate magnetic field of different strength $H_{\mathrm{AC}}$ and a frequency of $f=450 \mathrm{kHz}$. The course of the curve $T(t)$ is a measure of the power released in a unit volume of the sample. The analysis of calorimetric results allowed an estimate of the contribution of relaxation and hysteresis loss mechanisms to total energy losses in the hyperthermal effect under the influence of an alternating magnetic field. It is clear from Figure 8 that, depending on the pyrolysis temperature, time form few to 50 seconds is sufficient to heat the system up to required temperature exceeding $40^{\circ} \mathrm{C}$. The calorimetric measurements and theoretical considerations (not presented in this paper) [25] showed that the relaxation processes dominate in the heat generation mechanism for the Ni\#C composite pyrolysed at $673 \mathrm{~K}$. For the samples pyrolysed at 773 and $873 \mathrm{~K}$, significant values of coercivity and remanence, give substantial contributions to the energy losses for hysteresis. The Ni\#C composites generated sufficient heat to propose them for thermal therapies. The statement that superparamagnetic nanoparticles NPs are able to generate impressive levels of heat at lower magnetic fields compared to ferromagnetic ones is not true for this type of magnetic carbon nanocomposites.
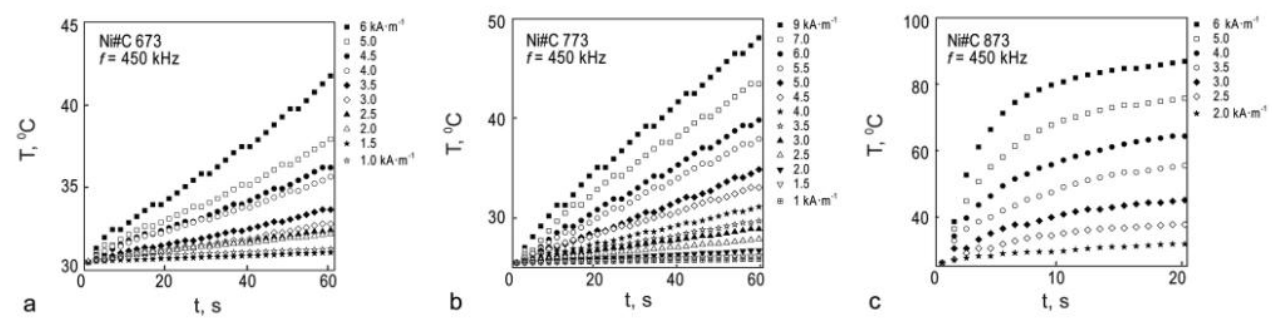

Figure 8. Time-temperature curves for samples obtained at various pyrolysis temperatures: (a) $673 \mathrm{~K}$, (b) $773 \mathrm{~K}$, and (c) $873 \mathrm{~K}$, for different values of the magnetic field $H_{\mathrm{AC}}$, of frequency $f=450 \mathrm{kHz}$ 
The impact of carbon composites on the survival of bone cells MG-63 in vitro, was also assessed. Representatives from each material group were chosen, i.e. Co\#C 873, $\mathrm{Fe}_{3} \mathrm{C \# C}$ and Ni\#C 873, respectively, to illustrate how a type of material influences the cell survival. The pure growth medium was treated as positive control and constituted the reference for all the results. The fluorescence value obtained with the control was deemed to indicate $100 \%$ viability.

After the morphological observation and quantitative tests performed, it appeared that the XTT test is not an appropriate assay for the evaluation of cytotoxicity. It was due to the fact that XTT test is a calorimetric assay, while it was found that the tested samples change both the colour of the culture medium and its $\mathrm{pH}$. These factors can affect the reliability of this type of assay; therefore, the main emphasis was placed on the morphological evaluation and PicoGreen assay results.

PicoGreen assay results indicated that for Co-containing composite there was negligible change in the number of cells exposed on the extracts at the concentration of 3.12 and $6.25 \mathrm{mg} / \mathrm{ml}$ (fluorescence c.a. 97 and $90 \%$ of control, respectively), as seen in Figure 9). For extract of the test sample at the concentration of $12.5 \%$ almost $20 \%$ reduction of the number of cells was recorded, which is still considered a no cytotoxic in accordance with ISO 10993 $5: 2009^{261}$ ISO . Only for the composite extract at a concentration of 25 and $50 \mathrm{mg} / \mathrm{ml} \mathrm{moderate}$ cytotoxicity was observed (reduction of cell number to 17 and $16 \%$, respectively).

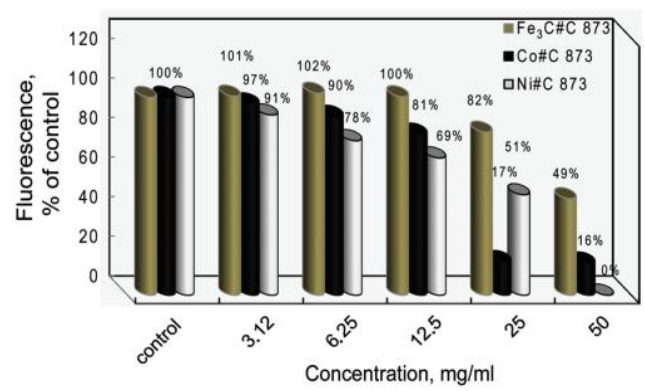

Figure 9. PicoGreen assay results performed after $24 \mathrm{~h}$ incubation of MG-63 cells in the presence of extracts prepared from the carbon composites pyrolysed at $873 \mathrm{~K}$

Viability of cells, incubated in the presence of extracts based on $\mathrm{Fe}_{3} \mathrm{C} \# \mathrm{C}$ composites, at concentration of $6.25,12.5,25$ and $50 \%(3.12,6.25,12.5,25 \mathrm{mg} / \mathrm{ml}$ respectively), was in the range of $82-102 \%$ of control, indicating on a none-cytotoxic effect of these extracts on the mammalian cells. However, when concerning the extract at the highest concentration (100\%, or $50 \mathrm{mg} / \mathrm{ml}$ ) reduction of cell viability to c.a. $49 \%$ of control was observed. This suggests a mildly cytotoxic effect of the tested specimen, but only when cells are exposed to the highest concentration extract.

The MG-63 cells incubated in extracts prepared from Ni\#C composite seemed to cause larger cytotoxic effect compared to $\mathrm{Co \# C}$ and $\mathrm{Fe}_{3} \mathrm{C} \# \mathrm{C}$ composites. In case of extracts at concentration of 6.25 and $12.5 \mathrm{mg} / \mathrm{ml}$ effect on mammalian cells can be described as slightly cytotoxic (reduction of cell viability to 78 an $69 \%$, respectively). The $50 \%$-extract can be assigned as mildly cytotoxic, whereas for the $100 \%$ one $(50 \mathrm{mg} / \mathrm{ml})$ cytotoxicity response was rated as severe based on the activity relative to values obtained for the control. 


\section{CONCLUSIONS}

The three-step procedure, applied in these studies, enables fabrication of magnetic carbon nanocomposites, composed of nanocrystallites stabilized in a carbon matrix.

Because the size of composite particles is in the micrometres size range it predispose them predominantly for in vitro applications such as magnetic bioseparation. However, the size of microparticles can be refined by milling in a ball mill, which enables their further selection for a particular application.

The method used for fabrication of the carbon nanocomposites enables control of the magnetic nanocrystallites size and thus their magnetic properties.

The mesoporous carbon composites with relatively high surface area are believed to be potentially applied for the adsorption of drugs and biomolecules. It is further facilitate by the existence of plentiful of various surface oxygen-containing functional groups on the carbon composite surface ensuring the linkage of biomolecules.

The relaxation processes dominate in the heat generation mechanism for the Ni\#C composite pyrolysed at $673 \mathrm{~K}$. For the samples pyrolysed at 773 and $873 \mathrm{~K}$, significant values of coercivity and remanence, give substantial contributions to the energy losses for hysteresis. The Ni\#C composites generated sufficient heat to propose them for thermal therapies.

The PicoGreen assay results confirmed that the composites containing $\mathrm{Fe}_{3} \mathrm{C}$ are non-cytotoxic or exhibit slightly cytotoxic effect at the highest concentration of composite particle. Majority of the Ni\#C and Co\#C composites was characterized as slightly or moderately cytotoxic. Only the extracts at a concentration of 25 and $50 \mathrm{mg} / \mathrm{ml}$ were assessed as highly cytotoxic.

\section{LITERATURE}

[1] F. YU, L. ZHANG, Y.Z. HUANG, et al., The magnetophoretic mobility and superparamagnetism of core-shell iron oxide nanoparticles with dual targeting and imaging functionality, Biomaterials 31, 5842-8 (2010).

[2] S.R. RUDGE, T.L. KURTHZ, C.R. VESSELY, et al., Preparation, characterization, and performance of magnetic iron-carbon composite microparticles for chemotherapy, Biomaterials 21, 1411-20 (2000).

[3] J. JOHNSON, T. KENT, J. KODA, C. PETERSON, S. RUDGE, G. TAPOLSKY, The MTC technology: a platform technology for the site-specific delivery of pharmaceutical agents, European Cells and Materials 3 (2), 12-5 (2002).

[4] M. IZYDORZAK, A. SKUMIEL, M. LEONOWICZ, et al., Thermophysical and magnetic properties of carbon beads containing cobalt nanocrystallites, Inter. Journ. of Thermophysics A. 33, 627-39 (2012).

[5] SKUMIEL, M. IZYDORZAK, M. LEONOWICZ, et al., Thermophysical and magnetic properties of carbon beads containing nickel nanocrystallites, Inter. Journ. of Thermophysics A. 32, 1973-85 (2011).

[6] J.M. NAM, C.S. THAXTON, C.A. MIRKIN, Nanoparticles-based bio-bar codes for the ultrasensitive detection of proteins, Science 301, 1884-6 (2003).

[7] F. PATOLSKY, Y. WEIZMANN, E. KATZ, et al., Magnetically amplified DNA assays (MADA): sensing of viral DNA and single-base mismatches by using nucleic acid modified magnetic particles, Angew. Chem. Int. Ed. 42, 2372-6 (2003)

[8] P. POUPONNEAU, J.Ch. LEROUX, S. MARTEL, Magnetic nanoparticles encapsulated into biodegradable microparticles steered with an upgraded magnetic resonance imaging system for tumour chemoembolization, Biomaterials 30, 6327-32 (2009).

[9] Z.M. SAIYED, S.D. TELANG, C.N. RAMCHAND, Application of magnetic technique in the field of drug discovery and medicine, BioMagn. Res. Technol. 1(2), 1-8 (2003).

[10] Ch.S.S.R. KUMAR, F. MOHAMMAD, Magnetic nanomaterials for hyperthermia-based therapy and controlled drug delivery, Adv. Drug Deliv. Rev. 63, 789-808 (2011).

[11] A.D. POMOGAILO, G.I. DZHARDIMALIEVA, Frontal polymerization of metal-containing monomers: achievements and problems, Polym. Sci. Ser. A 46, 250-63 (2004).

[12] S. REICH, C. THOMSEN, Raman spectroscopy of graphite, Physical and Engineering Sciences 362, 2271-88 (2004). 
[13] C. BENY-BASSEZ, J.N. ROUZAUD, Characterization of carbonaceous material by correlated electron and optical microscopy and Raman microspectroscopy, Scanning Electron Microscopy 1, 119-32 (1985)

[14] V. DATSYUK, M. KALYVA, K. PAPAGELIS, Chemical oxidation of multiwalled carbon nanotubes, Carbon 46, 833-40 (2008).

[15] X.M. SUN, Y.D. LI, Colloidal carbon spheres and their core/shell structures with noble-metal nanoparticles Angew. Chem. Int. Ed. Engl. 43, 597-601 (2004).

[16] J.J. HOST, J.A. BLOCK, K. PARVIN, et al., Effect of annealing on the structure an magnetic properties of graphite encapsulated nickel and cobalt nanocrystals, J. Appl. Phys. 83, 793-801 (1998)

[17] C.H.P LUPIS, Chemical Thermodynamics of Materials, North-Holland, New York NY (1983), pp. 66 and 74

[18] I.M. LIFSHITZ, V.V. SLYOZOV, The kinetics of precipitation from supersaturated solid solutions J. Phys. Chem. Solids 19, 35 (1961).

[19] D. FAN, L.-Q. CHE, S.P. CHEN, et al., Phase field formulations for modeling the Ostwald ripening In twophase systems, Computational Materials Science 19, 329-336 (1998).

[20] B. BOKHONOV, M. KORCHAGIN, The formation of graphite encapsulated metal nanoparticles during mechanical activation and annealing of soot with iron and nickel, J. Alloy Compd. 333, 308-20 (2002).

[21] M.P. FERNÁNDEZ-GARCÍA, P. GORRIA, M. SEVILLA et al., Enhanced protection of carbon-encapsulated magnetic nickel nanoparticles through a sucrose-based synthetic strategy, J. Phys. Chem. C 115, 5294-300 (2011).

[22] E.P. SAJITHA, V. PRASAD, S.V. SUBRAMANYAM, S. ETO, K. TAKAI, T. ENOKI, Synthesis and characteristics of iron nanoparticles in a carbon matrix along with the catalytic graphitization of amorphous carbon, Carbon 42, 2815-20 (2004).

[23] R. FISCHER, H. KRONMULLER, The role of the exchange inter-action in nanocrystalline isotropic $\mathrm{Nd}_{2} \mathrm{Fe}_{14} \mathrm{~B}$-magnets. J. Magn. Magn. Mater. 91, 225-33 (1999).

[24] D.J. SELLMYER, C.P. LUO, Y. QIANG, et al., Handbook of Thin Film Materials, Vol. 5, Academic Press, San Diego (2002), Chapter 7.

[25] M. IZYDORZAK, A. SKUMIEL, M. LEONOWICZ, A.D. POMOGAILO, G.I. DZHARDIMALEVA, Thermophysical and magnetic properties of carbon beads containing cobalt nanocrystallites, J. Thermphysics 33 (4) (2012) 637-639. 